\title{
A strangely-shaped protection area
}

\section{Anna-Sophie Pirtscher}

Keywords: Natura 2000, species in need of strict protection, biotop network

\section{Abstract}

The habitats of many animal and plant species are being lost because of human intervention. The expansion of settlement and industrial areas, the drainage of wetlands for cultivation, building check dams across bodies of water and the expansion of infrastructure are squeezing species so much that many are classified as endangered. Insurmountable obstacles on migratory routes present such huge barriers that animals are isolated in their populations, no genetic exchange can take place, and potential habitats can no longer be populated. The forestry operation at Inneres Salzkammergut, Österreichische Bundesforste (ÖBf; Austrian federal forest corporation) is counteracting this through active habitat design, networking and protection.
Profile

\section{Protected area}

Natura 2000 biotop

network

\section{Mountain range}

\section{Alps, Austria}

\section{In the heart of Austria}

Ausseerland lies $750 \mathrm{~m}$ above sea level in the centre of Austria (see Figure 1), and includes lakes, bogs and forests. It is bordered by the Totes Gebirge mountains in the north and the Styrian Dachstein plateau in the south. For hundreds of years, salt mining operations took place in this area. Until the turn of the century, the forest was cut primarily to make charcoal used in the process of making salt. The effects of this can be seen in today's natural landscape. The ÖBf owns a large part of the land. What is particularly special is that many of the species and habitats found in Ausseerland are greatly endangered elsewhere in Austria. These natural resources should be saved for future generations through the establishment of various protected areas and sustainable management.

\section{Natural jewels in the Ausseerland region}

In Ausseerland, species that are classified as species in need of strict protection according to the Habitats Directive occur in high population numbers compared to the rest of Austria. These include Triturus carnifex (ital-

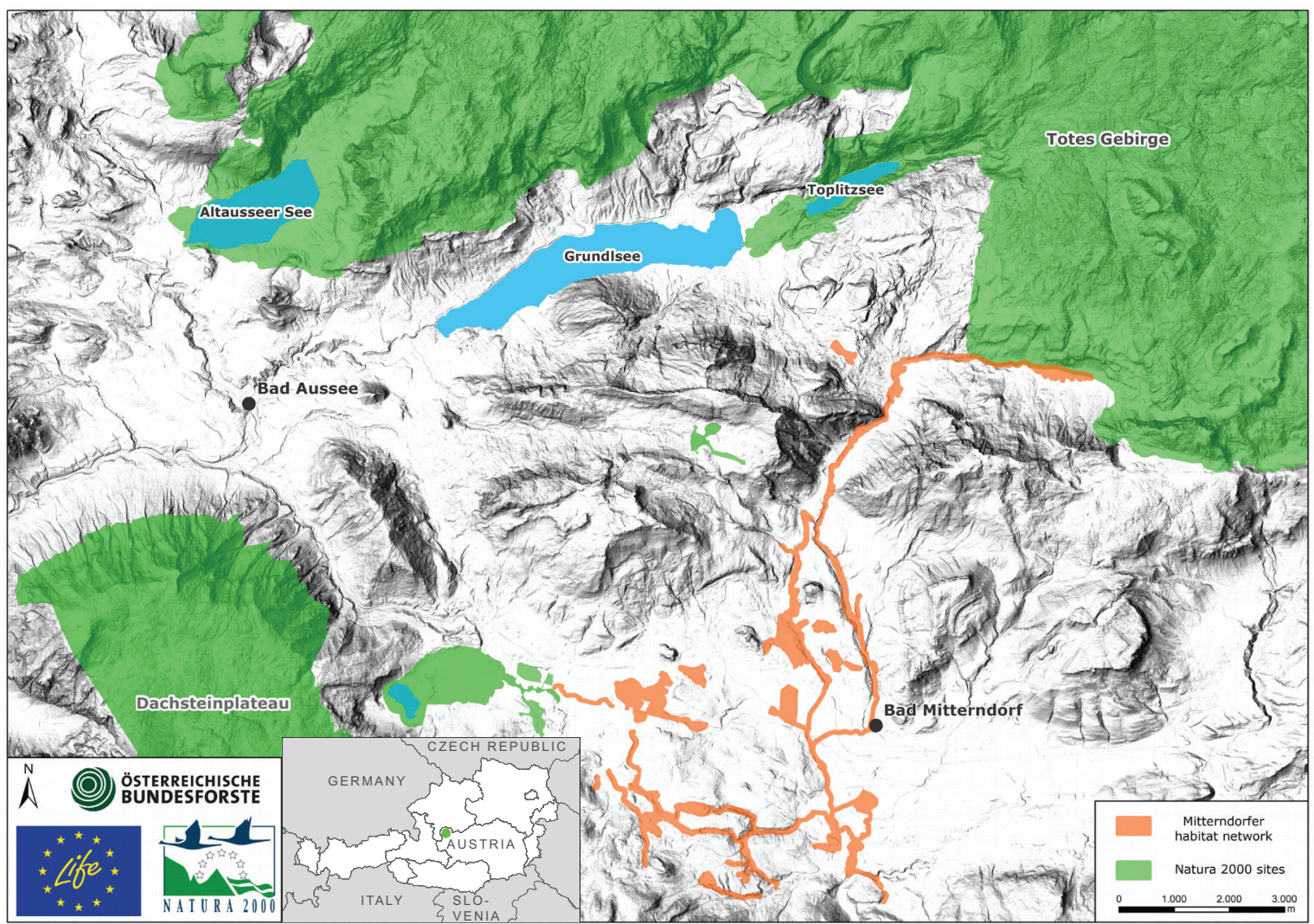

Figure 1 - Ausseerland is a region of Styria, in the centre of Austria. (C) ÖBf-Archiv / S. Ackermann 
ian crested newt, see Figure 2), Bombina variegata (yellow-bellied toad, see Figure 3), Cottus gobio (bullhead, see Figure 4), Austropotamobius torrentium (stone crayfish, see Figure 5) and many more. In addition, there are some smaller areas of bogs which are protected per se and as a habitat for butterflies, some types of orchid and dragonflies.

\section{Funding projects}

Since July 2013, the forestry operation at Inneres Salzkammergut has been implementing the LIFE+ project Natural woodlands, bogs and habitat network in Ausseerland, which is funded by the European Union. The focus is on active habitat design and networking for the protection of natural resources. 5.7 million euros are being invested over six years in preparing management plans, implementing specific measures and monitoring, as well as in extensive, accompanying public relations work. The aim is to improve the four existing Natura 2000 sites and to gain new knowledge about the diversity of species.

\section{Passage for aquatic creatures}

Technical structures in rivers and streams to protect people and their buildings, as well as course-straightening operations for a more efficient use of land, can be found in Ausseerland just as much as in the rest of Austria. Only recently has the negative impact on migrating fish and other aquatic creatures become a cause for concern.

The Salza and the Rödschitzbach in Bad Mitterndorf are two bodies of water that connect the Totes Gebirge with the Kemet Mountains around the Ausseerland valley area. They are valuable ecological networks and provide habitats for protected species such as C. gobio and $A$. torrentium, but also for many other aquatic organisms. Previously a concrete ground sills and drop structures of $15 \mathrm{~cm}$ in height or more presented a barrier for C. gobio, a small fish without a swim bladder, which was unable to migrate further upstream. Stone crayfish were also reluctant to cross this channelled river area without many hiding places. Half of each of the five concrete ground sills in the Rödschitzbach was removed by the LIFE+ project and replaced by structures of large armour stones in the area immediately downstream in order to stabilise the bed of the waterway. Small-scale gravel and crushed stone banks have formed due to the altered flow patterns and are used by species which spawn on gravel beds. Felled trees are anchored to the banks with steel ropes as so-called dead trees, to provide aquatic organisms with hiding places on the one hand, and to stop them drifting away in high waters on the other. Two high barriers, which previously held back crushed rock, were deliberately breached (see Figure 6). All the work was designed and carried out by experienced project partners so that the

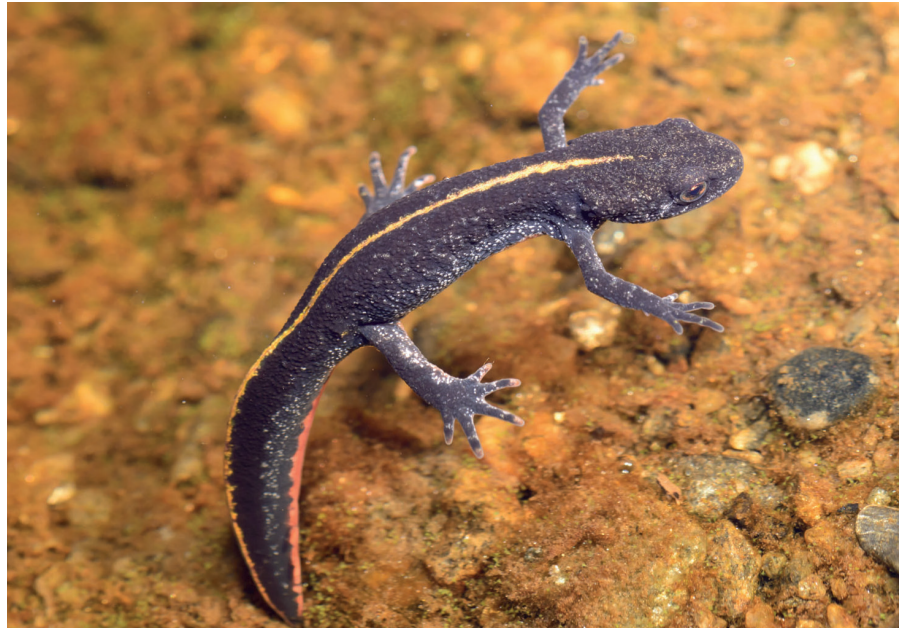

Figure 2 - Triturus carnifex (C) ÖBf-Archiv / W. Simlinger

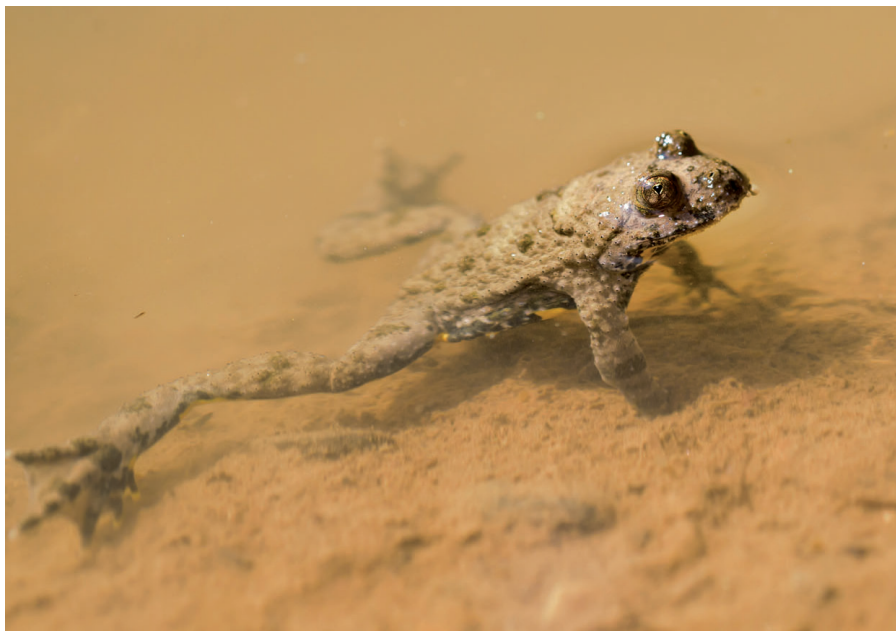

Figure 3 - Bombina variegata (C) ÖBf-Archiv / W. Simlinger

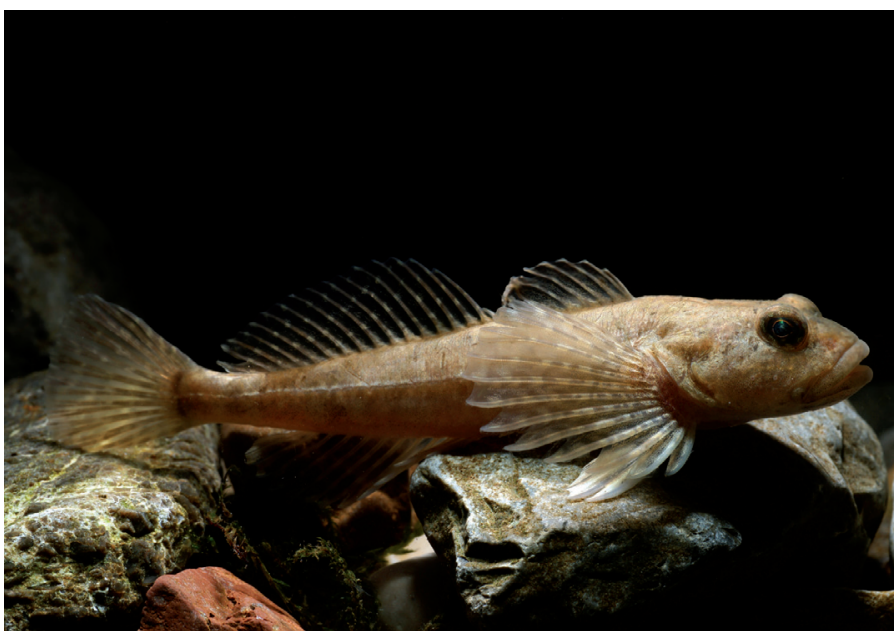

Figure 4 - Cottus gobio (C) ÖBf-Archiv / C. Ratschan

safety of people and buildings in the future could be guaranteed.

\section{Paddling ponds for newts}

T. carnifex is found mainly in the heavily used valleys of Ausseerland. Here, the range and network of ponds 


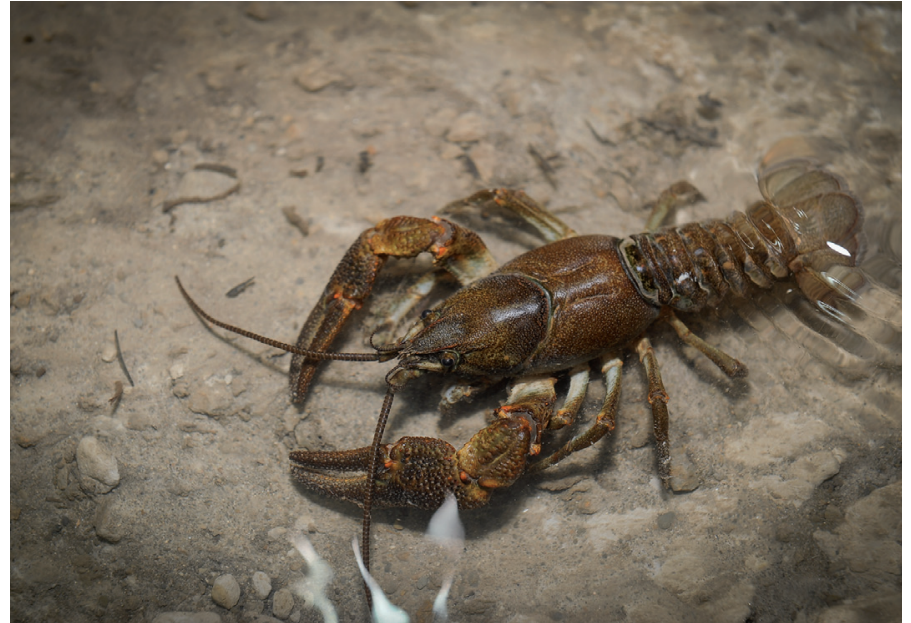

Figure 5 - Austropotamobius torrentium (C) ÖBf-Archiv/S. Bramesbuber

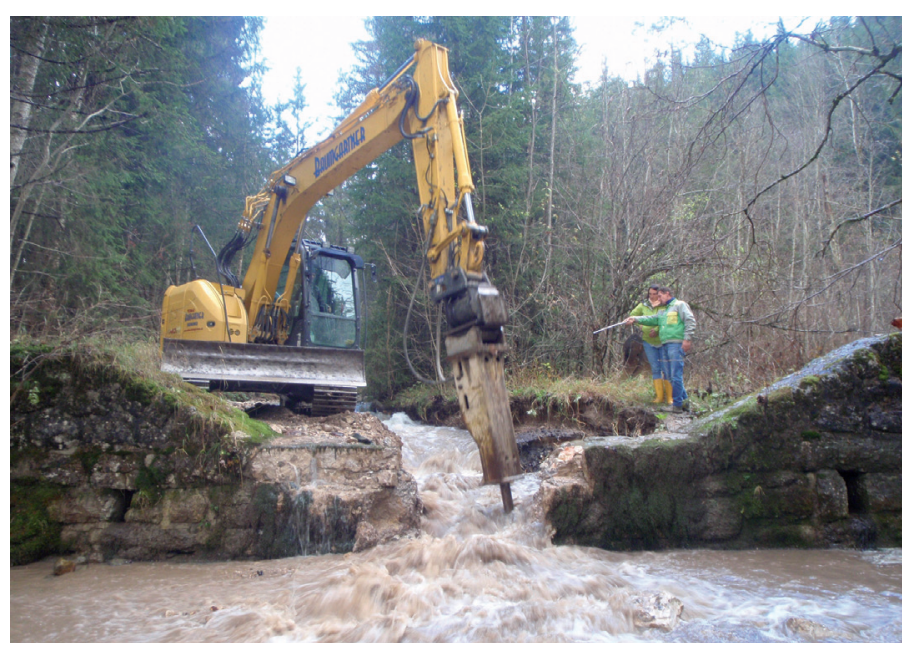

Figure 6 - Heavy mashinery breaks through the barrier and the river bed becomes continous again. (C) H. Haseke

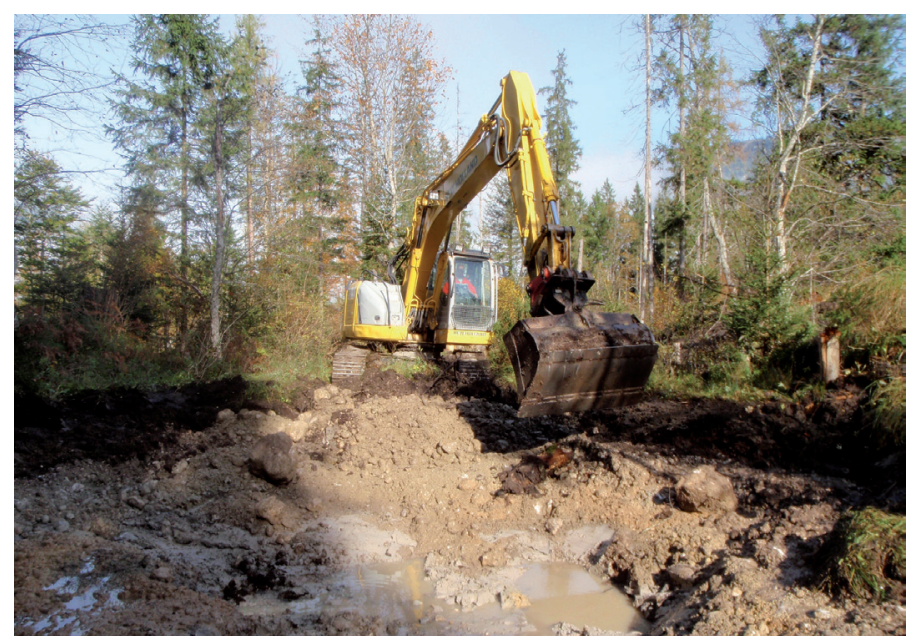

Figure 7 - Heavy mashinery dredges a pond. (C) H. Haseke

is minimal. As for many other species, the lack of habitat is the greatest problem facing this particular newt. There used to be more ponds in the landscape, but these have become silted up or deliberately backfilled by humans in order to gain productive land. In some of them, fish were released, which eat the spawn of amphibians. A suitable pond for newts like T. carnifex should be at least $1.5 \mathrm{~m}$ deep and have an area of 100 $200 \mathrm{~m}^{2}$. Structures such as rootstocks or larger stones in the water or at the edge are ideal. In waterlogged areas and old pond locations, the earth is excavated and moved to the side mechanically. The area at the edge is then flattened. At first glance, the ponds look like large mud holes and not at all attractive. However, they soon fill with water and the edges become green and overgrown within a year (see Figures 7 and 8).

The LIFE+ project has created 41 new ponds, at an optimal walking distance from each other for the newts of 500 to $1000 \mathrm{~m}$. In addition, small shallow pools are created in the immediate area in hollows made by the excavator shovel. These small bodies of water heat up faster and are attractive spawning waters for B. variegata. The new biotopes are not used exclusively by the two protected species: other animals also benefit from them. Grass frogs, common toads, smooth newts, alpine salamanders and dragonflies are also found here. Water beetles go on the hunt for insect larvae. In addition, grazing livestock and wild animals can use them to drink from, and humans get the chance to listen to a free frog concert!

\section{Climbing aids for amphibians}

Migratory amphibians, such as B. variegata, the grass frog and others, which often make their way along forest and agricultural roads in the spring, run the risk of being run over by vehicles on the one hand, and of falling into and dying in cattle grids on the other. Although the concrete boxes beneath the grids themselves have a small opening so that water can drain away after snow melts or heavy rainfall, this usually becomes blocked, preventing the animals' escape from the box, where they starve to death.

This is why 32 cattle grids in the valley area have been equipped with climbing aids (see Figure 9) - simple metal ramps, designed specifically for this purpose, which can be installed on two sides in the grid boxes. Even small animals can use these ramps to escape from captivity.

\section{Special piping facilitates proliferation}

Within the forests, roads run over watercourses which are inhabited by the indigenous $A$. torrentium: the roads do not flood after heavy rain because the streams are channelled under the roads through pipes. However, at the end of the pipes, there are often steep drops that present an insurmountable obstacle for the crayfish. The way over land, and therefore on the forest road, is usually too strenuous for the animals to take and no less dangerous.

As part of the LIFE+ project, the usual pipe culverts under the forest roads were replaced by tubes 
with specially welded cross-beams (see Figure 10). Substrate gets caught on the cross-beams, meaning that the pipes are easier for $A$. torrentium to pass through. In addition, the pipes are installed in the stream bed itself; any remaining differences in level between pipe and the actual floor of the stream bed are mitigated by placing stones for the crayfish to climb over. This in turn paves the way for the crayfish to pass underneath the forest roads and expand into new habitats.

\section{Caring for bogs}

Bogs rank among the world's most endangered habitats. The use of peat as a fuel and natural remedy, and the creation of drainage ditches have long-term adverse effects on bogs. To stabilise the water balance as much as possible so that the peat moss can grow again, the most important measure is to close the drainage ditches. To do this, $4 \mathrm{~cm}$-thick larchwood tongue-andgroove posts are used, with a mechanism to interlock the planks. The posts, which are tapered at the bottom, are driven through the peat, next to each other, into the mineral soil, thus forming a dam (see Figures 11 and 12). These so-called sheet piles dam up the water and direct it sideways to the moor area. The peat moss can grow again, form peat, and the bog survives.

Earlier, with traditional agriculture using manual labour, it was normal to cut bog areas on a regular basis. This manual work is no longer viable, and our species-rich cultural landscape is suffering as a result. Once-open spaces are becoming covered with bushes and trees; moors are becoming overgrown. Species that are dependent on an open landscape with a rich offering of flowers are losing valuable habitat. Consequently, moor areas are now regularly cleared of growing spruce trees and alder buckthorn. Euphydryas aurinia, which needs the devil's bit (Succisa pratensis) as a nectar plant - and as a forage plant during its caterpillar stage - benefits from this.

\section{Result: strangely-shaped protection area}

To safeguard all the measures in the long term, the bogs, water bodies and accompanying strips of forest have been voluntarily designated by the forestry operation as a new Natura 2000 site - the Mitterndorfer biotope network - and governed by the province of Styria. The protected species and habitats are therefore protected natural resources, even in the event of a change in operational interest. There was no opposition to the nomination of the protection area, since only areas of the ÖBf are affected. What is new is that the selection of areas within the Natura 2000 territory is based on mappings and includes only areas that are technically relevant (see Figure 13). Otherwise, protected areas in Austria are large designated areas, and are not necessarily the result of surveys alone. The Mitterndorfer biotope network, an odd-shaped protected area, presents a challenge for its managers and super-

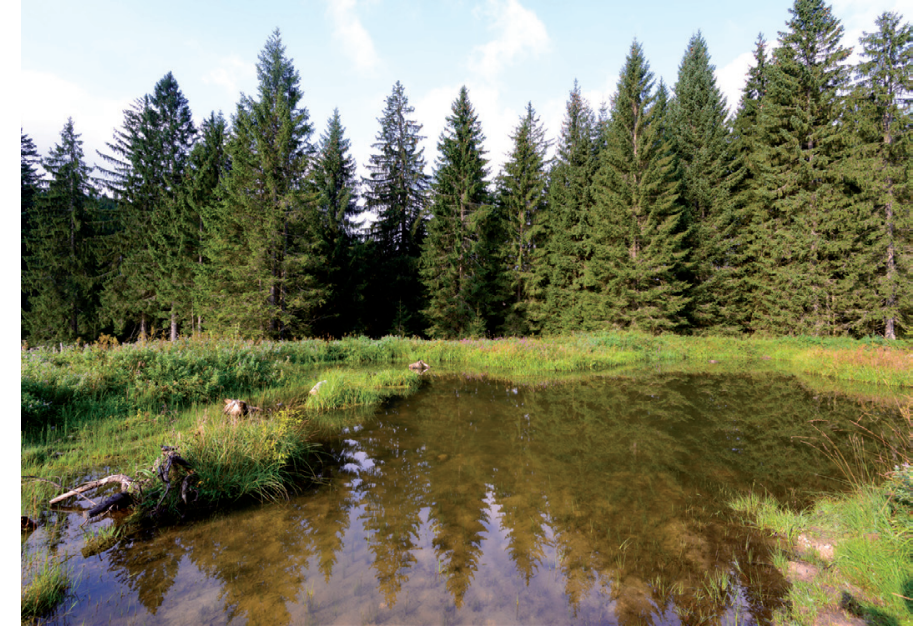

Figure 8-At first the pond looks muddy and unattractive, but after a year there are already amphibians using it for reproduction. (C) ÖBf-Archiv/W. Simlinger

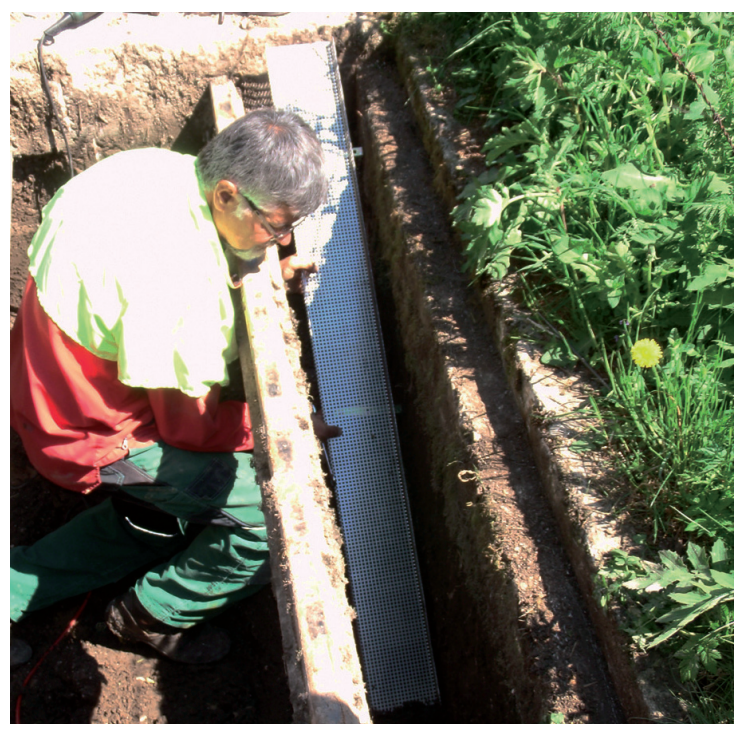

Figure 9 - Small metal ramps provide an exit route from the cattle grid. (C) H. Haseke

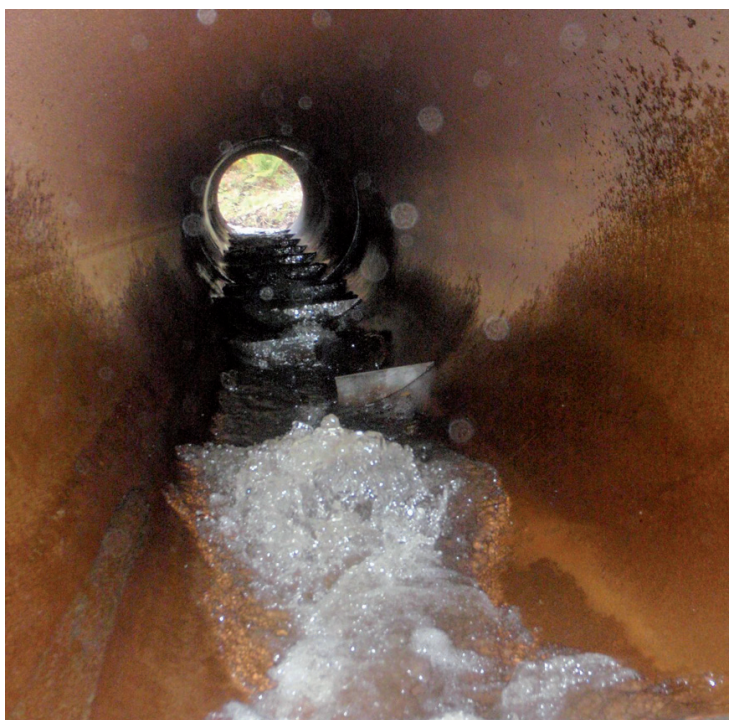

Figure 10 - Specially adapted pipes help the crayfish to pass under forest roads. (C) H. Haseke 

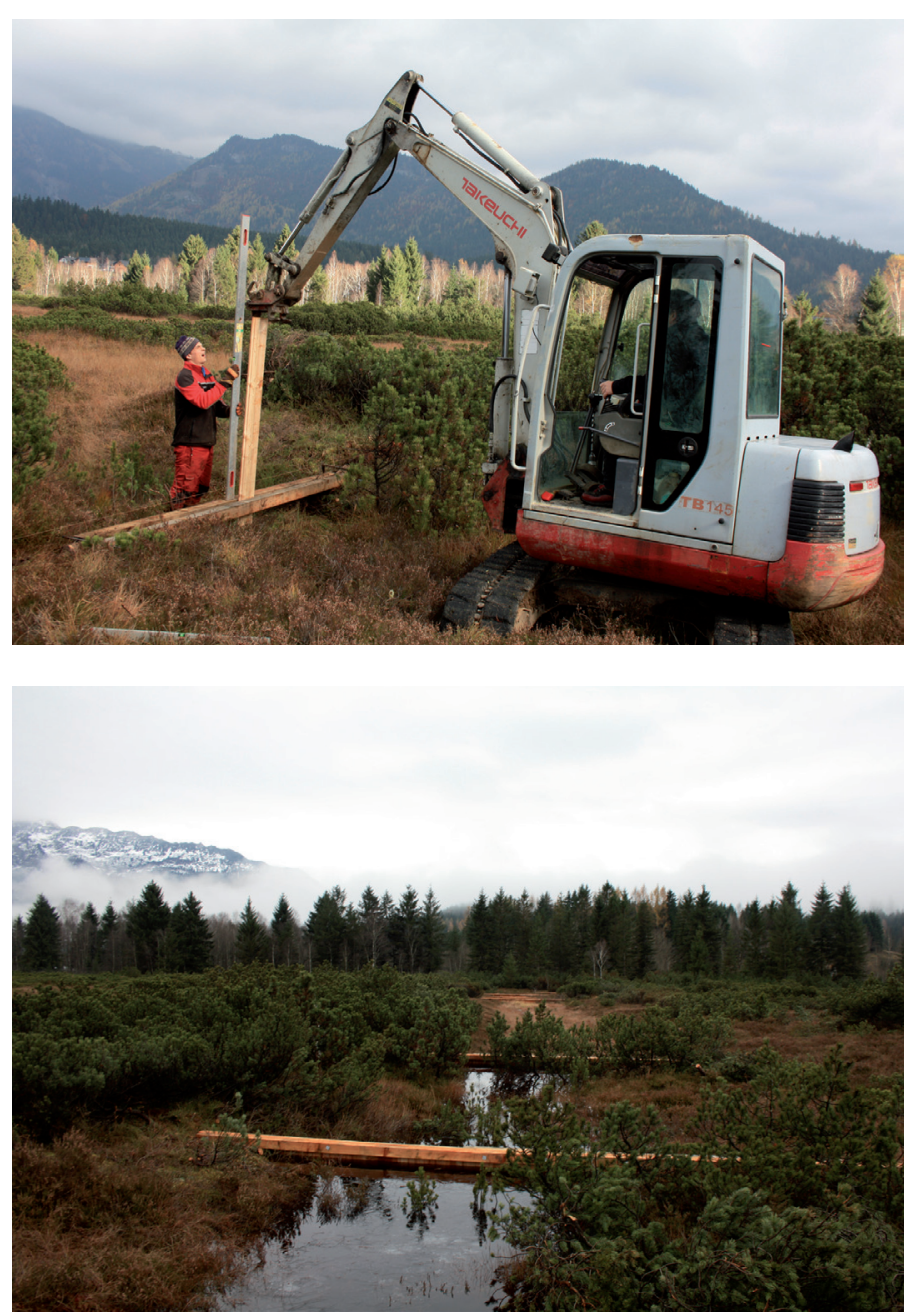

Figure 11 \& 12 - Larch planks are pushed with great precision down into the ground. Once the work is done, the water accumulates and spreads into the bog area. (C) ÖBf-Archiv/A.-S. Pirtscher

visors. There is a lot more that needs to be considered during the regular management of the forest. For example, if a protected area is affected by activities (e.g. logging, afforestation, expansion of tourist infrastructure), the management needs to evaluate whether this would endanger a species or not, but it is difficult to know just where members of the endangered populations might be found. Management plans with detailed maps should illustrate and facilitate this in the future.

\section{The future}

Despite the efforts made by the LIFE+ project Natural woodlands, bogs and habitat network in Ausseerland and the ÖBf's consideration of protected natural resources in its regular forestry management, it is still uncertain whether sufficient and well-networked habitats can be safeguarded in the long term. Large insurmountable obstacles remain, such as the railway line along which the chemical treatment of vegetation takes place, and the federal roads that cut through the valley. In addition, agriculture and soil sealing are being intensified for various projects. In Ausseerland, as is so typical of the Alps generally, a balancing act is needed between economic development and nature conservation.

\section{Further information}

Österreichische Bundesforste AG, LIFE+ Projekt Naturwald, Moore und Lebensraumverbund im Ausseerland 2017. Aktiv für Steinkrebs und Amphibien - Anregungen für Forstleute, Landwirte und Gewässerbewirtschafter Get active for stone crayfish and amphibians [In German]. Available at. www.bundesforste.at/uploads/publikationen/ Bundesforste-Folder_Aktiv_fuer_Steinkrebs_ Amphibien_2017.pdf

Schweizer Bundesamt für Umwelt 2017. Gewässer aufwerten für Mensch und Natur (DE/FR/IT). Available at: www.bafu.admin.ch/bafu/de/home/themen/ wasser/publikationen-studien/publikationen-wasser/ gewaesser-aufwerten.html

Landesforstverwaltung Baden-Würtemberg 2004. Fließgewässer im Wald. [In German] Available at: www. fva-bw.de/publikationen/sonstiges/fliessgewaesser_ im_wald.pdf

Streissl, F. \& W. Hödl 2002. Die jahreszeitliche Mobilität des Steinkrebses (Austropotamobius torrentium) im Biberbach (Niederösterreich). Österreichs Fischerei 55: 22-26. [In German] Available at: www.zobodat.at/ pdf/Oesterreichs-Fischerei_55_0022-0026.pdf

Weblinks

LIFE+ Projekt Ausseerland: www.bundesforste.at/ natur-erlebnis/life-projekt-ausseerland.html

Amphibians and reptiles in Austria:

www.herpetofauna.at

ARGE conservation: www.amphibienschutz.at

Forum crayfish: www.forum-flusskrebse.org

\section{Author}

\section{Anna-Sophie Pirtscher}

works as project manager of the LIFE+ Natural woodlands, bogs and habitat network in Ausseerland at Österreichische Bundesforste. After studying forestry and interning at CIPRA International, she now enjoys planning, creating and connecting habitats in the forest ecosystem, and developing sustainable management of protected areas. E-Mail: life_ausseerland@ bundesforste.at 